\title{
Ultrastructural localization of extracellular matrix proteins of the lymph node cortex: evidence supporting the reticular network as a pathway for lymphocyte migration
}

\author{
Gregg P Sobocinski ${ }^{1}$, Katherine Toy ${ }^{2}$, Walter F Bobrowski ${ }^{3}$, Stephen Shaw ${ }^{4}$, Arthur O Anderson ${ }^{5}$, Eric P Kaldjian ${ }^{6 *}$
}

\begin{abstract}
Background: The lymph node $(L N)$ is a crossroads of blood and lymphatic vessels allowing circulating lymphocytes to efficiently recognize foreign molecules displayed on antigen presenting cells. Increasing evidence indicates that after crossing high endothelial venules, lymphocytes migrate within the node along the reticular network (RN), a scaffold of fibers enwrapped by fibroblastic reticular cells (FRC). Light microscopy has shown that the RN contains specific extracellular matrix (ECM) proteins, which are putative molecular "footholds" for migration, and are known ligands for lymphocyte integrin adhesion receptors.

Results: To investigate whether ECM proteins of the RN are present on the outer surface of the FRC and are thus accessible to migrating lymphocytes, ultrastructural immunohistochemical staining of cynomolgus monkey LN was performed using antibodies to human ECM proteins that were successfully employed at the light microscopic level. The fibrillar collagens I and III were observed primarily within the reticular network fibers themselves. In contrast, the matrix proteins laminin, fibronectin, collagen IV, and tenascin were observed within the reticular fibers and also on the outer membrane surface of the FRC.
\end{abstract}

Conclusions: These findings suggest a molecular basis for how the RN functions as a pathway for lymphocyte migration within the lymph node.

\section{Background}

The lymph node is a highly specialized organ in which circulating lymphocytes encounter processed foreign substances that are displayed on antigen presenting cells (APC). Blood-borne lymphocytes enter the node by transmigrating across high endothelial venules (HEV) [1-3]. From there, $T$ and $B$ lymphocytes travel to their specific compartments within the node $[4,5]$. The reticular network (RN) is a highly branched scaffold of interconnecting fibers each of which is enwrapped by thin cytoplasmic processes of fibroblastic reticular cells [6,7]. It has been postulated that lymphocytes and APC use the $\mathrm{RN}$ as the route for trafficking within the node [4,5,8-10]. Recently, Bajénoff and Miller separately

\footnotetext{
* Correspondence: eric.kaldjian@umich.edu

${ }^{6}$ Hearing Health Science, Ann Arbor, MI, USA

Full list of author information is available at the end of the article
}

demonstrated the use of the reticular network as a path for lymphocyte trafficking using in vivo video imaging techniques $[11,12,8]$.

Immunohistochemical staining at the light microscopic level has demonstrated that the RN contains a variety of extracelluar matrix (ECM) proteins, many of which are known ligands for integrin cell surface adhesion receptors [7]. Although these proteins could theoretically provide molecular "footholds" for cell trafficking along the $\mathrm{RN}[4,13]$, optical resolution does not allow the precise localization of ECM within the RN. It remains possible that these ECM proteins are present only within the fiber core - which is most of the volume of the RN - and not on the outer membrane surface of the enwrapping FRC. If so, the ECM proteins will not be available to migrating cells as stepping stones for movement, and would be unlikely to contribute to trafficking. We therefore undertook an ultrastructural 
immunohistochemical study in cynomolgus monkey lymph nodes to test the hypothesis that ECM proteins are accessible to migrating cells.

\section{Methods}

Care and Use of Laboratory Animals

All work was conducted in accordance with the current guidelines for animal welfare (Guide for the Care and Use of Laboratory Animals, 1996, Animal Welfare Act, 1996, as amended in 1970, 1976 and 1985, 9 CFR Parts $1,2,3)$.

\section{Light Microscopy}

Lymph node slices from an adult female cynomolgus monkey were immersion-fixed in 10\% neutral buffered formalin for 24 hours then routinely processed and embedded in paraffin. Paraffin sections were cut at 3 microns and air dried overnight. Heat-induced epitope retrieval, where indicated, was performed in a pressure cooker set at $5 \mathrm{lbs}$ of pressure and $109^{\circ} \mathrm{C}$ while immersed in either EDTA pH 8.0 or citrate buffer $\mathrm{pH}$ 6.0 (Biocare Medical). Slides were cooled for 10 minutes, rinsed, and then stained and developed with diaminobenzidine using the automated NexesTM IHC Staining System (Ventana Medical Systems) using the manufacturer's reagents and protocols. Protease treatment was employed where indicated (Protease 2, Ventana). Primary antibody incubation time was 32 minutes. (See Table 1.)

\section{Electron Microscopy}

Lymph node pieces from an adult female cynomolgus monkey was immersed and minced in $1.25 \%$ glutaraldehyde and $2 \%$ paraformaldehyde fixative, fixed for $2-3$ hours, rinsed, and stored in $0.1 \mathrm{M}$ sodium phosphate buffer. The tissues were then dehydrated and embedded in LR White acrylic resin (Polysciences Inc.), and cold-cured under $365 \mathrm{~nm}$ UV light using a Pelco ${ }^{\circ}$ UVC2 Cryo Chamber (Ted Pella Inc). Ultrathin tissue sections were collected on nickel grids, and stained using the following steps: (1) 10 minute etch with $10 \% \mathrm{H}_{2} \mathrm{O}_{2}$; (2) 10 minute pre-block with $1 \%$ BSA in $\mathrm{PBS}$ pH 7.4; (3) primary antibody incubation overnight at $4^{\circ} \mathrm{C}$ in PBS/BSA; (4) 2 hour secondary antibody incubation at room temperature in PBS/BSA; (5) 5 minute fixation in cacodylate-buffered $2.5 \%$ glutaraldehyde $\mathrm{pH} 7.2$; (6) two, 5 minute silver enhancement incubations utilizing an IntenSE ${ }^{\mathrm{st}} \mathrm{M}$ Silver Enhancement Kit (Amersham, RPN 491); (7) uranyl acetate and lead citrate counter stains of 8 minutes each. Rinses were performed between steps where appropriate. Primary antibodies and secondary $20 \mathrm{~nm}$ gold-conjugated anti-IgG antibodies were used at the dilutions listed in Table 2 .

\section{Quantification}

Stained grids were viewed on a Philips CM 100 BIOTWIN transmission electron microscope. Images were captured using a digital camera (AMT Advantage CCD Camera System). For each stain, five separate fields (original magnification $=2,850 \times$, area $=$ approximately 65 square micrometers) were selected that included representative reticular fibers and associated fibroblastic reticular cells. These images were scored independently by two investigators (GPS, EPK) by counting silverenhanced gold particles and categorizing according to location as described in Figure 1. A mean score was calculated. Variability in counts between investigators was within $3-5 \%$.

In some cases, the area of evaluation contained a reticular fiber surrounded by a FRC, a part of which bordered a second adjacent fiber directly (which was in turn enwrapped by another FRC). These areas were understood to represent fiber branching points. Particles present on this membrane-fiber interface were

Table 1 Histochemical (L.M.) Antibody Information

\begin{tabular}{|c|c|c|c|c|c|c|c|}
\hline $\begin{array}{l}\text { Primary } \\
\text { Antibody }\end{array}$ & $\begin{array}{l}\text { Type, Species, } \\
\text { lgG-type (Clone) }\end{array}$ & Dilution & $\begin{array}{l}\text { Slide } \\
\text { Pretreatment }\end{array}$ & Source & $\begin{array}{l}\text { Secondary } \\
\text { antibody }\end{array}$ & Dilution & Source \\
\hline $\begin{array}{l}\text { von } \\
\text { Willebrand } \\
\text { Factor }\end{array}$ & Polyclonal, Rabbit anti-Human IgG & $1: 2000$ & $\mathrm{P} 2=16 \mathrm{~min}$ & Dako, A 0082 & $\begin{array}{l}\text { Universal } \\
\text { link }\end{array}$ & Prediluted & $\begin{array}{l}\text { Ventana Medical } \\
\text { Systems }\end{array}$ \\
\hline Collagen I & Polyclonal, Rabbit anti-Human lgG & $1: 100$ & $\begin{array}{l}\text { (HIER) EDTA } 5 \text { min \& } \\
\text { P2 = } 16 \text { min }\end{array}$ & $\begin{array}{l}\text { Biogenesis, } \\
2150-0020\end{array}$ & $\begin{array}{l}\text { Universal } \\
\text { link }\end{array}$ & Prediluted & $\begin{array}{l}\text { Ventana Medical } \\
\text { Systems }\end{array}$ \\
\hline Collagen III & Polyclonal, Rabbit anti-Human IgG & $1: 100$ & $\begin{array}{l}\text { (HIER) EDTA } 5 \text { min \& } \\
\text { P2 }=16 \text { min }\end{array}$ & $\begin{array}{l}\text { Biogenesis, } \\
2150-0100\end{array}$ & $\begin{array}{l}\text { Universal } \\
\text { link }\end{array}$ & Prediluted & $\begin{array}{l}\text { Ventana Medical } \\
\text { Systems }\end{array}$ \\
\hline Laminin & Polyclonal, Rabbit anti-Mouse IgG & $1: 25$ & $\mathrm{P} 2=32 \mathrm{~min}$ & Cappel, 10765 & $\begin{array}{l}\text { Universal } \\
\text { link }\end{array}$ & Prediluted & $\begin{array}{l}\text { Ventana Medical } \\
\text { Systems }\end{array}$ \\
\hline Fibronectin & $\begin{array}{l}\text { Monoclonal, Mouse anti-Human } \\
\text { lgG1 (Clone 568) }\end{array}$ & 1:100 & $\mathrm{P} 2=32 \mathrm{~min}$ & $\begin{array}{l}\text { Novo Castra, } \\
\text { NCL-FIB }\end{array}$ & $\begin{array}{l}\text { Universal } \\
\text { link }\end{array}$ & Prediluted & $\begin{array}{l}\text { Ventana Medical } \\
\text { Systems }\end{array}$ \\
\hline Collagen IV & $\begin{array}{l}\text { Monoclonal, Mouse anti-Human } \\
\text { lgG1 (Clone CIV 22(1)) }\end{array}$ & $1: 100$ & $\mathrm{P} 2=16 \mathrm{~min}$ & Dako, M0785 & $\begin{array}{l}\text { Universal } \\
\text { link }\end{array}$ & Prediluted & $\begin{array}{l}\text { Ventana Medical } \\
\text { Systems }\end{array}$ \\
\hline
\end{tabular}


Table 2 Immunogold (E.M.) Antibody Information

\begin{tabular}{|c|c|c|c|c|c|c|}
\hline $\begin{array}{l}\text { Primary } \\
\text { Antibody }\end{array}$ & $\begin{array}{l}\text { Type, Species, } \\
\text { lgG-type (Clone) }\end{array}$ & Dilution & Source & $\begin{array}{l}\text { Secondary } \\
\text { antibody }\end{array}$ & Dilution & Source \\
\hline $\begin{array}{l}\text { von Willebrand } \\
\text { Factor }\end{array}$ & Polyclonal, Rabbit anti-Human IgG & $1: 200$ & Dako, A 0082 & $\begin{array}{l}\text { Goat anti- } \\
\text { Rabbit }\end{array}$ & $1: 100$ & $\begin{array}{l}\text { BBI International, EM. } \\
\text { GAR20 }\end{array}$ \\
\hline Collagen I & Polyclonal, Rabbit anti-Human lgG & 1:100 & $\begin{array}{l}\text { Biogenesis, 2150- } \\
0020\end{array}$ & $\begin{array}{l}\text { Goat anti- } \\
\text { Rabbit }\end{array}$ & $1: 200$ & $\begin{array}{l}\text { BBI International, EM } \\
\text { GAR20 }\end{array}$ \\
\hline Collagen III & Polyclonal, Rabbit anti-Human lgG & $1: 200$ & $\begin{array}{l}\text { Biogenesis, 2150- } \\
0100\end{array}$ & $\begin{array}{l}\text { Goat anti- } \\
\text { Rabbit }\end{array}$ & 1:100 & $\begin{array}{l}\text { BBI International, EM. } \\
\text { GAR20 }\end{array}$ \\
\hline Laminin & Polyclonal, Rabbit anti-Mouse lgG & $1: 200$ & Cappel, 10765 & $\begin{array}{l}\text { Goat anti- } \\
\text { Rabbit }\end{array}$ & $1: 50$ & $\begin{array}{l}\text { BBI International, EM. } \\
\text { GAR20 }\end{array}$ \\
\hline Fibronectin & $\begin{array}{l}\text { Monoclonal, Mouse anti-Human lgG1 (Clone } \\
\text { 568) }\end{array}$ & $1: 200$ & $\begin{array}{l}\text { Novo Castra, NCL- } \\
\text { FIB }\end{array}$ & $\begin{array}{l}\text { Goat anti- } \\
\text { Mouse }\end{array}$ & 1:100 & $\begin{array}{l}\text { BBI International, EM. } \\
\text { GAF20 }\end{array}$ \\
\hline Collagen IV & $\begin{array}{l}\text { Monoclonal, Mouse anti-Human lgG1 (Clone } \\
\text { CIV 22(1)) }\end{array}$ & 1:100 & Dako, M0785 & $\begin{array}{l}\text { Goat anti- } \\
\text { Mouse }\end{array}$ & $1: 50$ & $\begin{array}{l}\text { BBI International, EM. } \\
\text { GAF20 }\end{array}$ \\
\hline Tenascin-C & $\begin{array}{l}\text { Monoclonal, Mouse anti-Human lgG1 (Clone } \\
\text { TN2) }\end{array}$ & $1: 50$ & Dako, M0636 & $\begin{array}{l}\text { Goat anti- } \\
\text { Mouse }\end{array}$ & $1: 100$ & $\begin{array}{l}\text { BBI International, EM. } \\
\text { GAF20 }\end{array}$ \\
\hline
\end{tabular}

considered part of the "outer reticular fiber" region rather than the "outer membrane" of FRC, since ECM here would not be accessible to migrating lymphocytes.

\section{Results}

\section{Light microscopy immunohistochemistry}

Staining of monkey lymph node using anti-human ECM antibodies revealed a pattern similar to that observed in human lymph node $[7,10,14]$. Figure 2 shows representative images of collagen I and IV and fibronectin stains. Staining is observed along the reticular fibers and around blood vessels, where the fibers form sheaths that join the endothelial basement membrane, but is absent in endothelial cells. In contrast, von Willibrand Factor (vWF), an endothelial marker, is present in the endothelial cells only, and not the fibers. It is apparent that the limits of optical resolution do not allow determination of whether the ECM proteins are present on the outer membrane of the FRCs, within the reticular cells themselves, or within the fibers. (See Figure 2)

\section{Ultrastructural immunohistochemistry}

To technically evaluate the post-embedding immunohistochemical method, we stained monkey LN with antibody directed against von Willebrand factor (vWF). Silver-enhanced immunogold particles marked endothelial cells of the HEV present in the lymph node cortex. There was virtually no label observed in the subjacent endothelial basement membrane and background staining was minimal. Since staining of reticular fibers was equivalent to background levels throughout the section, we used the vWF stain as a negative control for nonspecific staining in the quantitative assessment of ECM proteins (see Figure 3B and below). Since fibrils of

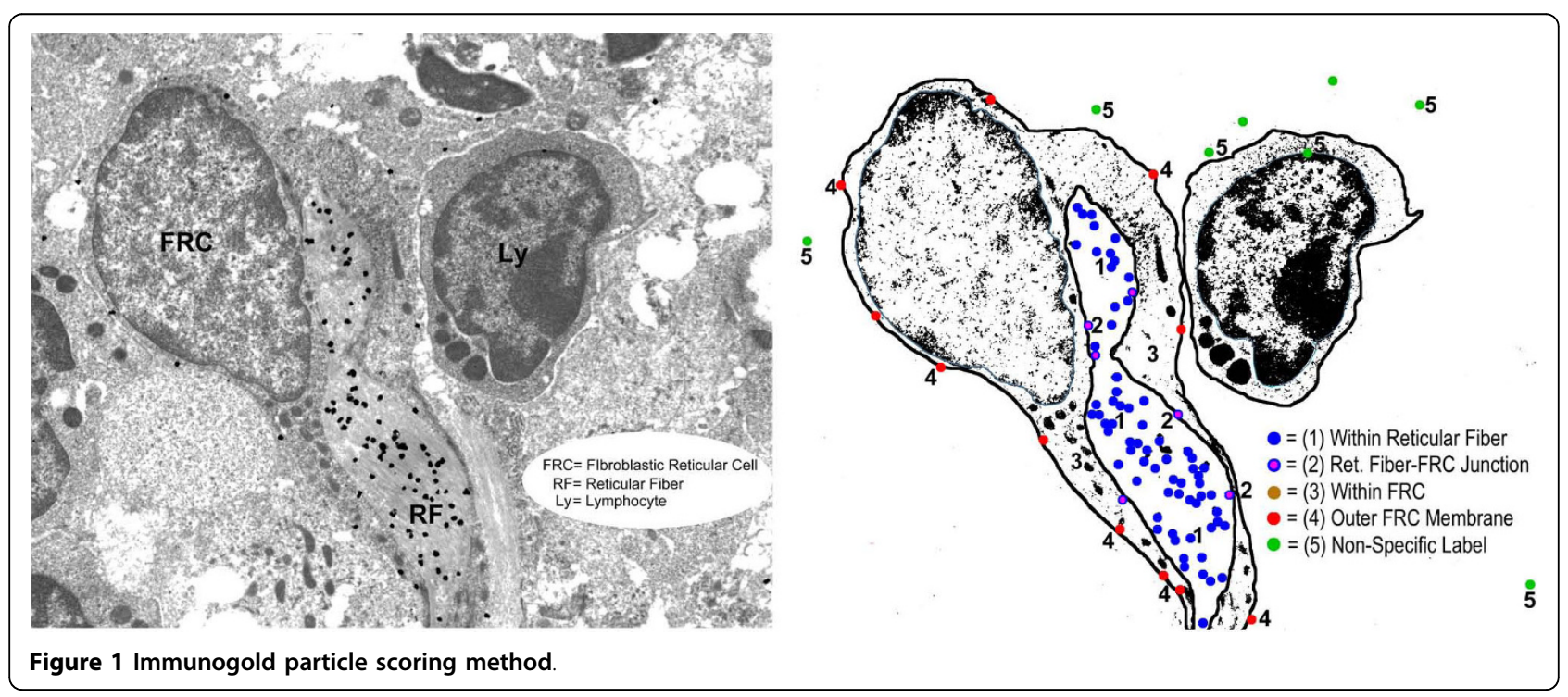




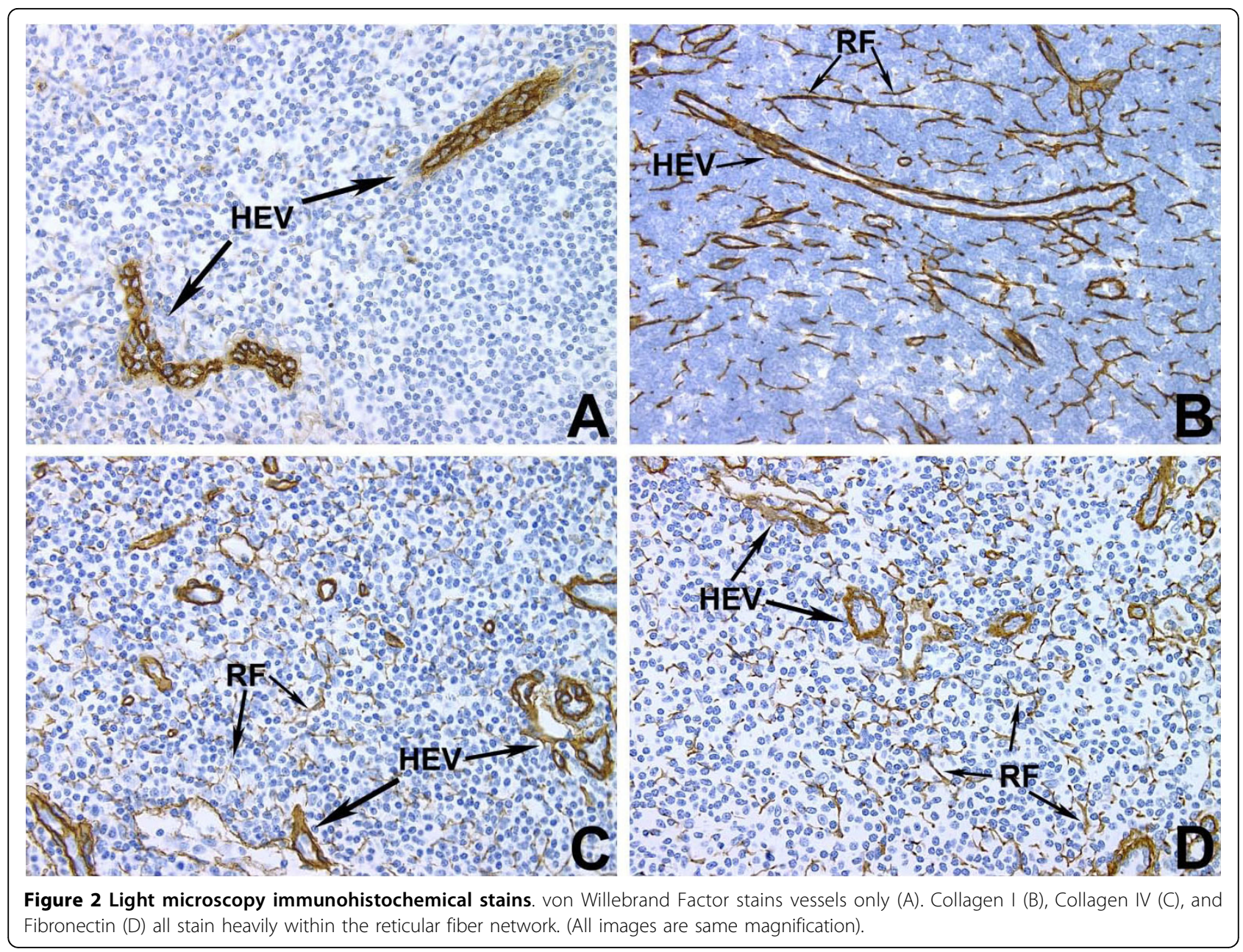

collagens I and III are known to be present within the reticular fibers $[7,10,15]$, we used stains for these collagens as positive controls. Label for both collagens was observed on the fibrils seen within the fiber, but not in the FRC or the surrounding tissues. It was noted that cross-sections of reticular fibers labeled less densely than did longitudinal sections (Figure 4B).

Collagen IV, laminin, tenascin, and fibronectin are basement membrane-associated ECM proteins (hereafter referred to simply as "basement membrane proteins"). Ultrastructural immunostaining revealed that these proteins are found within the reticular fiber, but not in the FRC cytoplasm (Figure 5). Unlike collagens I and III, however, the basement membrane proteins were also detected on the outer membrane of the FRC. Representative stains for tenascin, collagen IV, and fibronectin (Figure $5 \mathrm{~A}, \mathrm{C}$, D) demonstrate electron-dense particles along the outer membrane of a FRC that enwraps a reticular fiber. There were rare examples of fibronectin staining along the outer membrane of a lymphocyte (Figure 6).

\section{Quantitative localization of staining}

In order to provide a quantitative correlate to our qualitative observations, we developed a scheme to score the silver grains on five representative images for each antibody stain. Grains were classified according to their location and then tallied. Figure 1 shows an image with a corresponding diagram that summarizes the scheme. The following micro-anatomic categories were used: (1) within reticular fiber, (2) at reticular fiber-FRC border, (3) within FRC cytoplasm, (4) at the FRC outer surface, and (5) non-specific background. Table 3 shows the mean results of scoring of the images by two investigators. After initial scoring, categories (1) and (2) displayed no independent discriminatory value, and so were combined to yield a score of all grains associated with the reticular fiber. Since there was no appreciable staining of FRC cytoplasm by any of the antibodies, grains in category (3) were considered non-specific background and combined with category (5). Using the resulting three categories, location percentages were 


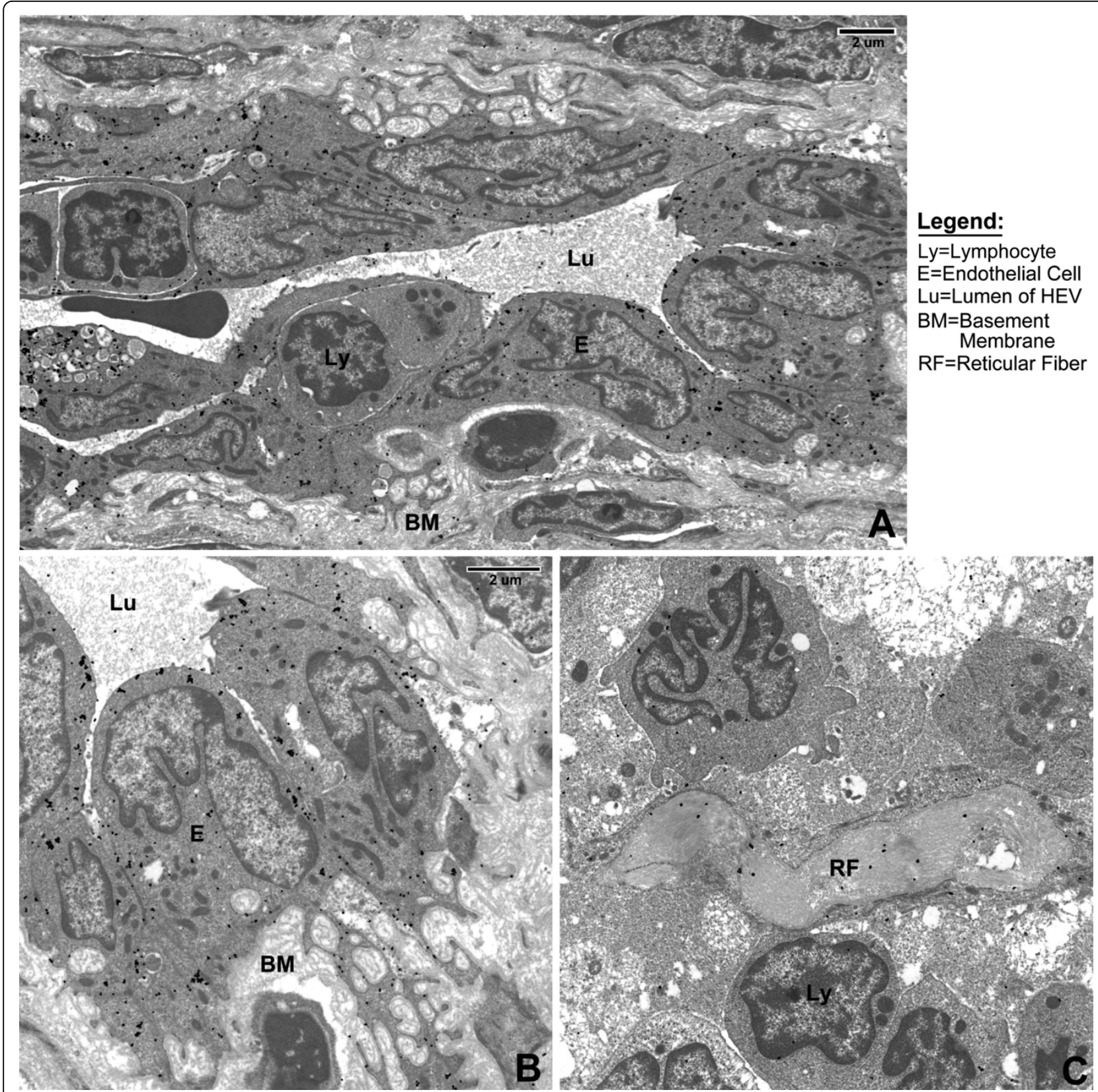

Figure 3 von Willebrand Factor immunoelectron microscopic staining. vWF is detected in the endothelial cells (A+B) of the HEV. Note lack of staining in the lymphocytes and the basement membrane matrix. Labeling in the reticular fiber (C) for von Willebrand Factor is non-specific. (Same magnification for images B and C).

calculated for each stain and pie charts were created to visualize the differences (Figure 7).

As explained previously, vWF was used as the negative control for reticular network staining. $76 \%$ of the (nonHEV) vWF label was in the background category, $23 \%$ within the reticular fiber, and 1\% was associated with the FRC outer membrane. For collagens I and III the pattern of staining was reversed, with approximately $80 \%$ of the label within the fiber and most of the remainder in background; FRC outer membrane staining was $1-2 \%$, comparable to vWF. Fibronectin and collagen IV stains yielded more than $80 \%$ of the label within the fiber, with background less than $10 \%$. Tenascin scored $66 \%$ within the fiber, and had background of $28 \%$. These three ECM stains had FRC outer membrane scores that ranged between 5 and $8 \%$, which were considerably increased from the $1 \%$ level of vWF. Staining for laminin was weakest of all the stains. Although only $45 \%$ of 


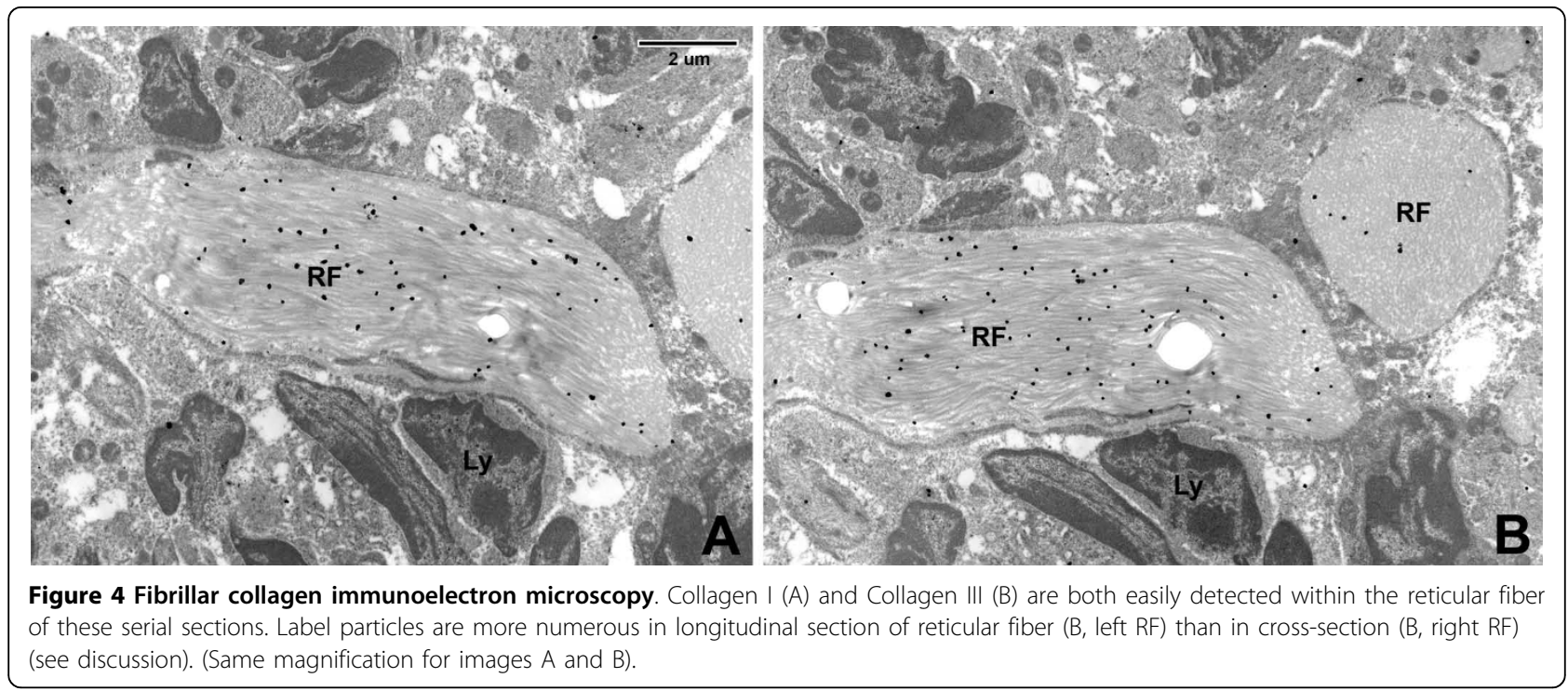

the laminin label was within the fiber, this was still twice the amount present in the vWF control, indicating positive staining. In addition, $4 \%$ of the grains were counted on the FRC outer membrane.

\section{Discussion}

It has been logically argued that both lymphocytes and antigen presenting cells travel along the RN to reach their respective compartments, since within the node cells "crawl but they can't swim" and thus need a road on which to travel $[16,7]$. Recently, video imaging of fluorescently labeled cells in a murine in vivo system has demonstrated real-time interaction between lymphocytes and the cells of the RN as they traffic through the node $[11,8]$. Fibronectin $[17,18]$, collagen IV, tenascin, and laminin, are basement membrane (BM) ECM components present within the $\mathrm{RN}[10,19-22]$ that are known ligands for integrin adhesion receptors, influencing cell taxis in vitro. Consequently, it has been postulated that such ECM proteins associated with the RN participate in cell migration across HEV and through the $\mathrm{LN}[23-26,16,7,5,9,10]$. The known ultrastructure of the $\mathrm{RN}$ does not require this to be the case, however, since the matrix components could be confined to the inner region of cable-like collagen fibrils, enwrapped by the thin FRC covering that separates it from the cavernous spaces of the nodal cortex [7]. Given the thinness of the wrapping, the precise location of the matrix proteins is optically irresolvable. By immunoelectron microscopy, however, we were able to localize them to specific regions of the RN.

Like the fibrillar collagens I and III that form the skeletal structure of the RN, the BM ECM proteins were observed within the reticular fiber. Previous studies have shown that the reticular network is a conduit for solutes to pass quickly from the afferent lymphatics entering the sub-capsular sinus to the HEV [27,28,5]. It is possible that these BM ECM components within the reticular fiber may participate in this solute transport. But unlike the fibrillar collagens, the BM ECM proteins were also detected on the outer membrane of the FRC - where they are accessible to migrating cells - at a level that was several times greater than background (see Figure 4; Tables 3 and Figure 7). Our observations thus confirm that the RN contains a complex mix of basement membrane-type proteins, and that they are present both within the fibers and on the outer FRC cell surface, where they can function as adhesion ligands for cell migration. This information provides experimental evidence for what had been hypothesized as the basis for cell crawling that is consistent with understood leukocyte motility. Moreover, this has been demonstrated in non-human primate lymph node, which closely resembles its human counterpart.

We observed the occasional absence of FRC cellular processes completely enwrapping the reticular fibers. It has been previously proposed that such gaps in the covering of the reticular fibers may allow direct access to reticular fiber ECM for migrating cells and thus provide the substrate for cell crawling. Ohtani [29] observed "fenestrations" in the FRC of rabbit Peyer's patches, most notably in flat cell processes. Ushiki [30] described incomplete wrapping of fibers in the rat node that was prominent in the medulla but rare in the deep cortex. Our studies were performed on non-human primate lymph nodes that closely resemble human lymph nodes, and investigated the $\mathrm{T}$ cell cortex, equivalent to the "deep cortex" of the rat. In this region the RN is made 


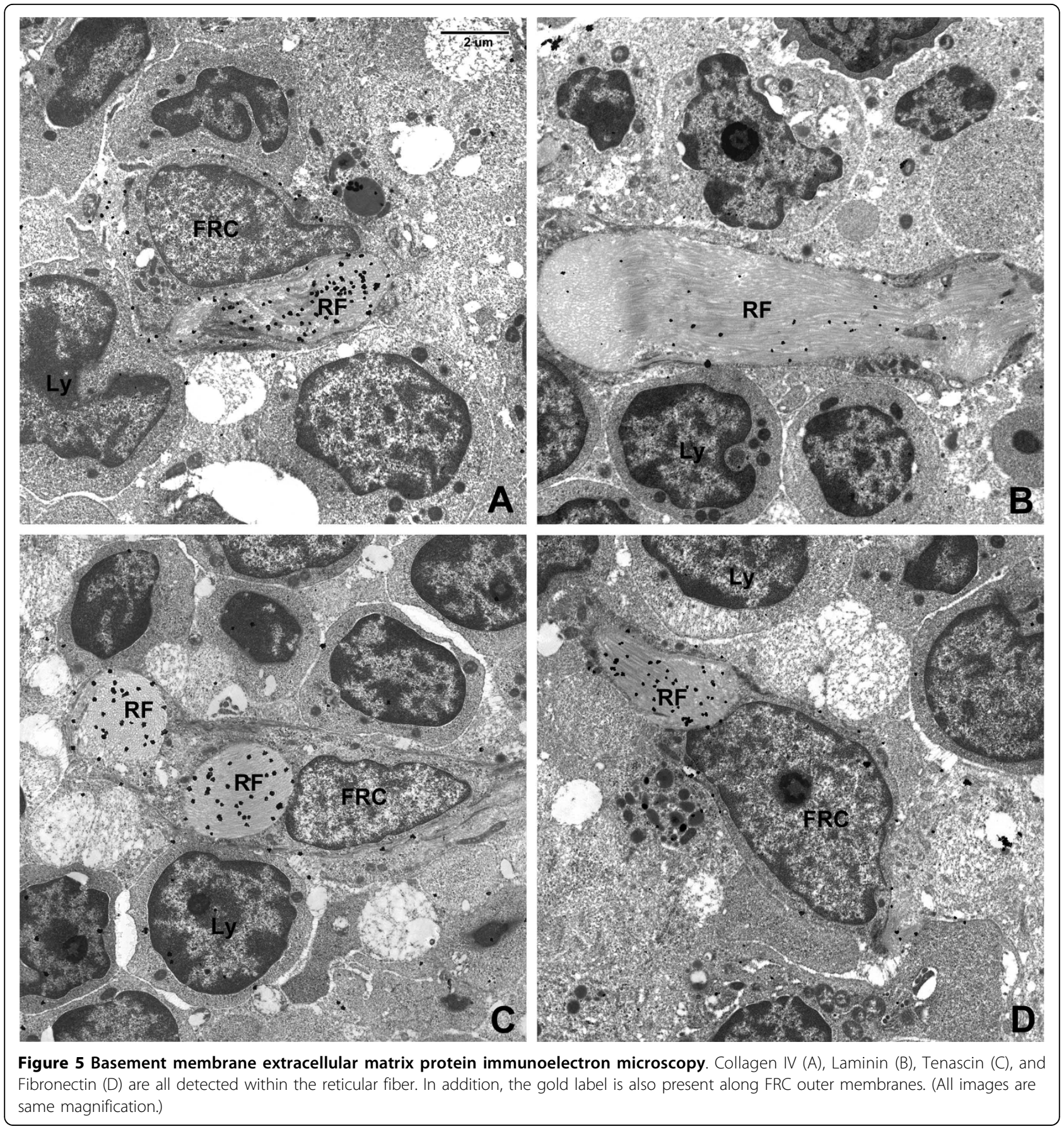

mostly of rope-like cords, rather than sheets, of fibers, and the FRC cell processes covering the fibers are not flat, but tubular. Our findings thus appear consistent with reports that exposed fibers in this region are not commonly found.

It is possible that we have underestimated the amount of membrane-associated ECM relative to fiber-associated ECM. The FRC membrane appears as a one-dimensional, linear structure in sections prepared for transmission electron microscopy. In contrast, the fiber typically appears as a broad, twodimensional plane. Thus, there is considerably less FRC membrane surface area than fiber surface area in the image fields evaluated. Our method tallied the total number of grains per image field, but did not calculate the density (the number of grains per unit area of membrane or of fiber) of the label within each region category, since defining the thickness of the 


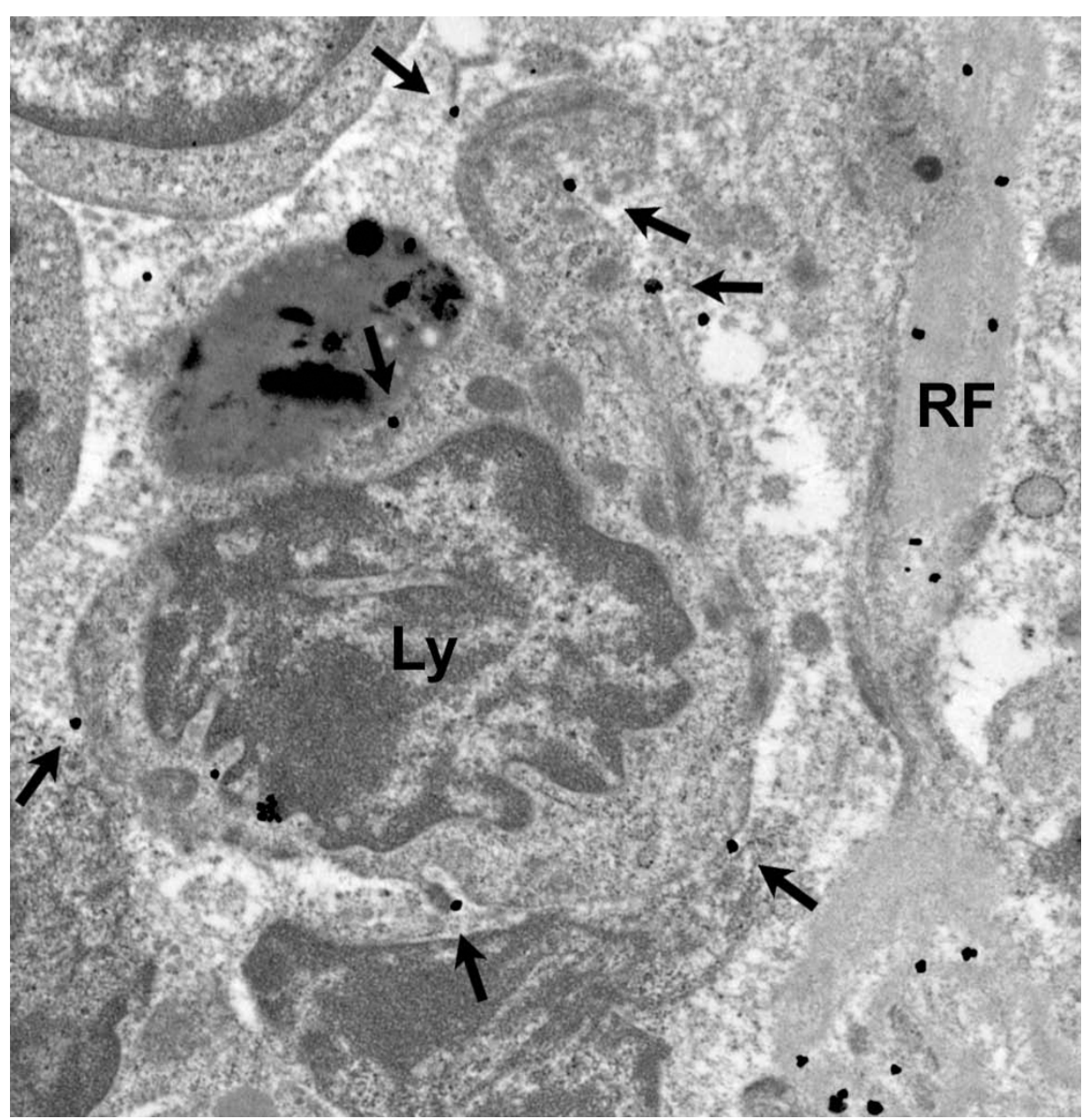

Figure 6 Fibronectin on lymphocyte surface. Several gold particles were observed along the cytoplasmic membrane of a lymphocyte.

membrane proved to be too subjective. The density, therefore, of the membrane-associated staining may actually be much higher relative to the density of the fiber-associated staining than the absolute number counts suggest.
Two other notable findings of the label particle distribution were observed in our study. Rarely, as shown in the fibronectin stain in Figure 6, silver grains were observed ringing the outer membrane of individual lymphocytes. It is possible that this represents synthesis by

Table 3 Data-gold particles counted per area

\begin{tabular}{|c|c|c|c|c|c|c|c|c|c|c|c|}
\hline & $\begin{array}{c}\text { Fibril } \\
\text { Associated }\end{array}$ & $\begin{array}{l}\text { FRC- } \\
\text { Fiber } \\
\text { Border }\end{array}$ & $\begin{array}{l}\text { Total } \\
\text { Within } \\
\text { Fiber }\end{array}$ & $\begin{array}{c}\text { FRC } \\
\text { Cytoplasm }\end{array}$ & $\begin{array}{l}\text { FRC Outer } \\
\text { Membrane }\end{array}$ & Background & $\begin{array}{l}\text { Background } \\
\text { Plus FRC } \\
\text { Cytoplasm }\end{array}$ & $\begin{array}{c}\text { Total } \\
\text { Grains } \\
\text { Counted }\end{array}$ & $\begin{array}{l}\text { Percent } \\
\text { Within } \\
\text { Fiber }\end{array}$ & $\begin{array}{c}\text { Percent } \\
\text { on FRC } \\
\text { Outer } \\
\text { Membrane }\end{array}$ & $\begin{array}{c}\text { Percent } \\
\text { Background } \\
* * *\end{array}$ \\
\hline vWF & 39 & 19 & 58 & 10 & 3 & 186 & 196 & 257 & 23 & 1 & 76 \\
\hline Collagen I & 168 & 17 & 185 & 9 & 4 & 24 & 33 & 222 & 83 & 2 & 15 \\
\hline Collagen III & 169 & 20 & 189 & 8 & 2 & 48 & 55 & 246 & 77 & 1 & 22 \\
\hline $\begin{array}{r}\text { Collagen } \\
\text { IV }\end{array}$ & 449 & 144 & 592 & 5 & 36 & 51 & 56 & 684 & 87 & 5 & 8 \\
\hline Laminin & 69 & 11 & 80 & 6 & 7 & 85 & 91 & 178 & 45 & 4 & 51 \\
\hline Tenascin & 257 & 99 & 356 & 13 & 32 & 138 & 151 & 538 & 66 & 6 & 28 \\
\hline Fibronectin & 275 & 84 & 359 & 4 & 34 & $37^{* *}$ & 40 & 433 & 83 & 8 & 9 \\
\hline
\end{tabular}

** 7 grains found on lymphocyte membrane in one fibronectin plate (See Figure 6.)

*** Immunogold granules found within the FRC (Figure 1, area 3) were added to the background tally (Figure 1, area 5) for determining the final statistics, since lack of significant FRC label implies merely background presence. 


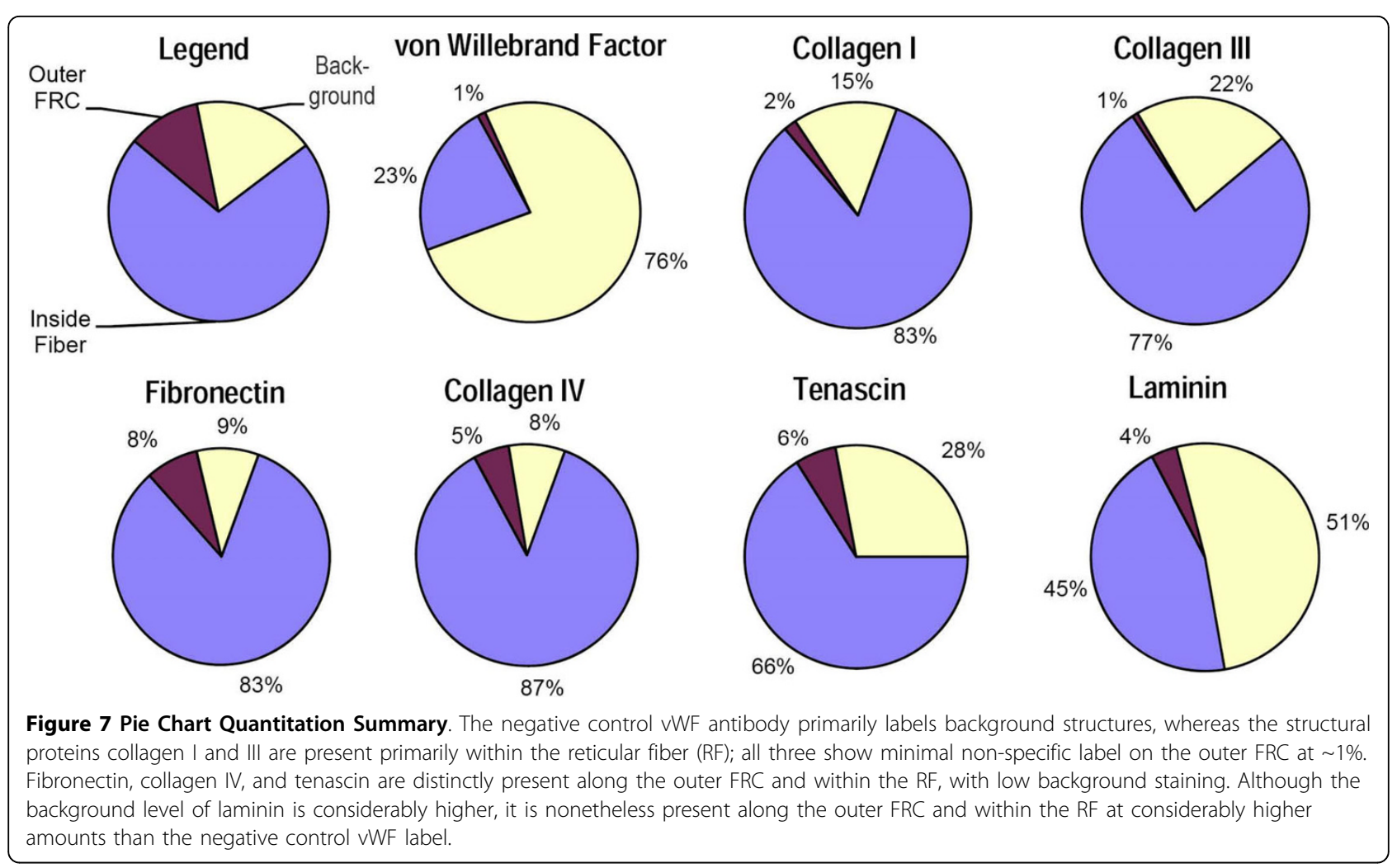

the lymphocyte, which then expresses the fibronectin at its surface; indeed, this has been described by Wagner and colleagues [31]. Alternatively, it may be that as the lymphocyte has traversed through and along the ECM of the node, fibronectin has "stuck" to integrin receptors on the cell surface. In addition, when staining for collagen I and III, we noted increased density of silver grains in longitudinal views of reticular fibers versus cross-sectional views (Figure 4-B). This may imply that the binding epitope is on the outer surface of the collagen triple helix, or somehow simply more accessible from the "side".

It is tempting to speculate on how the expression of adhesion ligands by FRC may guide the migration of cells to specific locations. Since the FRC wrap the reticular fibers, they are directly exposed to the solutes that pass through the FRC conduit from the sub-capsular sinus to the HEV. Thus, they are well-positioned to respond to factors that should logically prompt an increase in immune trafficking, and could increase their surface adhesion ligand density to encourage more efficient migration within the node and a corresponding higher rate of contact with APC [11].

These findings, if substantiated, may have implications for the understanding of immunological diseases [24]. Since direct contact between APC and lymphocyte essential to the generation of immune response, blocking such contact could suppress the abnormal immune activation in autoimmunity. One way to disallow contact is to keep the cells from being able to meet. If travel within the node is in fact regulated by BM ECM proteins on the outer surface of the RN, blocking ligandadhesion receptor binding with inhibitors could keep the cells from crawling to their correct compartments, and so dampen immune response. Conversely, in disorders of ineffective immunity, weakened immune response may exist from an endogenous inhibition of migration by unknown factors, or by too little BM ECM than required for adequate intra-nodal trafficking. Finally, it is conceivable that metastatic cancer cells may use similar mechanisms for traveling within the node. Thus, modulating the migrating cell-reticular network interaction may be a rational, albeit challenging, therapeutic approach.

\section{Conclusions}

We have demonstrated that ECM proteins known to be ligands of immune cell adhesion receptors are expressed on the outer surface of FRC within the cortex of nonhuman primate lymph nodes. These findings provide a molecular basis for how the RN may function as a pathway for cell migration within the lymph node. 


\section{List of abbreviations}

LN: Lymph Node; RN: Reticular Network; FRC: Fibroblastic Reticular Cell; ECM: Extracellular Matrix; APC: Antigen Presenting Cells; HEV: High Endothelial Venules; vWF: von Willebrand factor; BM: Basement Membranes.

\section{Authors' contributions}

GS- Electron microscope sample collection, immunocytochemistry, data collection and analysis. Created manuscript, plates, and figures. KT- Provided immunohistochemical data and interpretation. WB- Electron microscopy and immunohistochemistry consultation. Manuscript assembly and formatting assistance. SS- Collaboration toward the theory behind the research and interpretation of results. AA-Collaboration toward the theory behind the research and interpretation of results. EK- Designed the experiment. Data collection, interpretation, assisted manuscript writing, and editing. All authors read and approved the final manuscript.

\section{Authors' Information}

Gregg P. Sobocinski BSC. CEMT(MSA), QIHC(ASCP). Microscope Imaging Specialist, University of Michigan, Molecular, Cellular, \& Developmental Biology Department, Ann Arbor, MI, USA

Katherine Toy. HT(ASCP) QIHC(ASCP). Research Laboratory Specialist, University of Michigan, Pathology Department.(Internal Medicine/Oncology), Ann Arbor, MI, USA.

Walter F. Bobrowski BSc., CEMT(MSA). Senior Scientist, Pfizer Global R\&D, Groton, CT, USA.

Stephen Shaw PhD. Head of Human Immunology Section, Experimental Immunology Branch. NCl, Bethesda, MD, USA.

Arthur O. Anderson PhD Director, Office of Human Use and Ethics, Research Integrity Officer US Army Medical Research Institute of Infectious Diseases, Frederick, MD, USA.

Eric P. Kaldjian MD, Medical Director, Hearing Health Science, Ann Arbor, MI, USA

\section{Author details}

${ }^{1}$ MCDB Dept, University of Michigan, Ann Arbor, MI, USA. ²Pathology Dept, University of Michigan, Ann Arbor, MI, USA. ${ }^{3}$ Pfizer Global R\&D, Groton, CT, USA. ${ }^{4} \mathrm{NCl}$, Bethesda, MD, USA. ${ }^{5}$ USAMRIII, Frederick, MD, USA. ${ }^{6}$ Hearing Health Science, Ann Arbor, MI, USA.

Received: 20 April 2010 Accepted: 17 August 2010

Published: 17 August 2010

\section{References}

1. Anderson ND, Anderson AO, Wyllie RG: Specialized structure and metabolic activities of high endothelial venules in rat lymphatic tissues. Immunology 1976, 31(3):455-473.

2. Harris H, Miyasaka M: Reversible stimulation of lyphocyte motility by cultured high endothelial cells: mediation by L-selectin. Immunology 1995, 85(1):47-54.

3. Ebnet $\mathrm{K}$, Kaldjian EP, Anderson AO, Shaw S: Orchestrated Information Transfer Underlying Leukocyte Endothelial Interactions. Annu Rev Immunol 1996, 14:155-77.

4. Katakai T, Hara T, Lee JH, Gonda H, Sugai M, Shimizu A: A novel reticular stromal structure in lymph node cortex: an immuno-platform for interactions among dendritic cells, T cells and B cells. Int Immunol 2004 16:1133-1142

5. Katakai T, Hara T, Sugai M, Gonda H, Shimizu A: Lymph Node Fibroblastic Reticular Cells Construct the Stromal Reticulum via Contact with lymphocytes. J exp Med 2004, 200(6):783-795.

6. Hayakawa M, Kobayashi M, Hoshino T: Direct contact between reticular fibers and migratory cells in the paracortex of mouse lymph nodes: a morphological and quantitative study. Arch Histol Cytol 1988, 51:233-240.

7. Kaldjian EP, Gretz JE, Anderson AO, Shi Y, Shaw S: Spatial and molecular organization of lymph node T cell cortex: a labyrinthine cavity bounded by an epithelium-like monolayer of fibroblastic reticular cells anchored to basement membrane-like extracellular matrix. International Immunology 2001, 13(10):1243-1253.

8. Miller MJ, Wei SH, Cahalan MD, Parker I: Autonomous T cell trafficking examined in vivo with intravital two-photon microscopy. Proc Natl Acad Sci, USA 2003, 100(5):2604-2609.
9. Sixt M, Kanazawa N, Selg M, Samson T, Roos G, Reinhardt DP, Pabst R, Lutz MB, Sorokin L: The Conduit System Transports Soluble Antigens from the Afferent Lymph to Resident Dendritic Cells in the T Cell Area of the Lymph Node. Immunity 2005, 22:19-29.

10. Kramer RH, Rosen SD, McDonald KA: Basement-membrane components associated with the extracellular matrix of the lymph node. Cell Tissue Res 1988, 252:367-375.

11. Bajénoff $M$, Egen JG, Koo LY, Laugier JP, Brau F, Glaichenhaus N, Germain RN: Stromal Cell Networks Regulate Lymphocyte Entry, Migration, and Territoriality in Lymph Nodes. Immunity 2006, 25:1-13.

12. Miller MJ, Wei SH, Parker I, Cahalan MD: Two-Photon Imaging of Lymphocyte Motility and Antigen Response in Intact Lymph Node. Science 2002, 296:1869-1873.

13. Ogata T, Yamakawa M, Imai Y, Takahashi T: Follicular Dendritic Cells Adhere to Fibronectin and Laminin Fibers Via Their Respective Receptors. Blood 1996, 88(8):2995-3003.

14. Gretz JE, Anderson AO, Shaw S: Cords, channels, corridors and conduits: critical architectural elements facilitating cell interactions in the lymph node cortex. Immunological Reviews 1997, 156:11-24.

15. Sims TN, Dustin ML: The immunological synapse: integrins take the stage. Immunological Reviews 2002, 186:100-117.

16. Gretz EJ, Kaldjian EP, Anderson AO, Shaw S: Sophisticated strategies for information encounter in the lymph node. The reticular network as a conduit of soluble information and a highway for cell traffic. Journal of Immunology 1996, 157:495-499.

17. Kuusela P, Ruoslahti E, Engvall E, Vaheri A: Immunological interspecies cross-reactions of fibroblast surface antigen (fibronectin). Immunochemistry 1976, 13(8):639-42.

18. Stenman S, Vaheri A: Distribution of a major connective tissue protein, fibronectin, in normal human tissues. J Exp Med 1978, 147(4):1054-64.

19. Laikka A, Karjalainen H, Virtanen I, Autio-Harmainen H: Immuno-electronmicroscopic localization of types III pN-collage and IV collagen, laminin, and tenascin in developing and adult human spleen. Cell Tissue Res 1995, 282:117-127.

20. Crisa L, Cirulli V, Ellismanfi MH, Ishii JK, Elices MJ, Salomon DR: Cell Adhesion and Migration Are Regulated at Distinct Stages of Thymic T Cell Development: The Roles of Fibronectin, VLA4, and VLA5. J Exp Med 1996, 184:215-228.

21. Friedl P, Entschladen F, Conrad C, Zänker KS: CD4+ T lymphocytes migrating in three-dimensional collagen lattices lack focal adhesions and utilize 1 integrin-independent strategies for polarization, interaction with collagen fibers and locomotion. Eur J of Immunol 1998, 28:2331-2343.

22. Haston WS, Shields JM, Wilkinson PC: Lymphocyte Locomotion and Attachment on Two-dimensional Surfaces and in Three-dimensional Matrices. J Cell Biol 1982, 92:747-752.

23. Arencibia I, Suárez NC, Wolf-Watz H, Sundqvist KG: Yersina invasin, a bacterial B1-integrin ligand, is a potent inducer of lymphocyte Motility and migration to collagen type IV and fibronectin. Journal of Immunology 1997, 159:1853-1859.

24. Hauzenberger D, Klominek J, Bergström SE, Sundqvist KG: T lymphocyte migration: The influence of interaction via adhesion molecules, the $T$ cell receptor and cytokines. Critical Reviews in Immunology 1995, 15(3\&4):285-316.

25. Lidington $E$, Nöhammer C, Dominguez M, Ferry B, Rose ML: Inhibition of the transendothelial migration of human lymphocytes but not monocytes by phosphodiesterase inhibitors. Clin Exp Immunol 1996, 104:66-71.

26. Gorfu G, Virtanen I, Hukkanen M, Lehto VP, Rousselle P, Kenne E, Lindbom L, Kramer R, Tryggvason K, Patarroyo M: Laminin isoforms of lymph nodes and predominant role of _5-laminin(s) in adhesion and migration of blood lymphocytes. Journal of Leukocyte Biology 2008 , 84:701-712.

27. Gretz JE, Nordbury CC, Anderson AO, Proudfoot AEl, Shaw S: Lymph-based chemokines and other low molecular weight molecules reach high endothelial venules via specialized conduits while a functional barrier limits access to the lymphocyte microenvironments in lymph node cortex. Journal of Experimental Medicine 2000, 192(10):1425-1439.

28. Sainte-Marie G, Peng FS: Diffusion of a lymph-carried antigen in the fiber network of the lymph node of the rat. Cell Tissue Res 1986, 245:481-486. 
29. Ohtani O, Kikuta A, Ohtsuka A, Murakami T: Organization of the Reticular Network of Rabbit Peyer's Patches. The Anatomical Record 1991 229:251-258.

30. Ushiki T, Ohtani O, Abe K: Scanning Electron Microscopic Studies of Reticular Framework in the Rat Mesenteric Lymph Node. The Anatomical Record 1995, 241:113-122.

31. Wagner C, Bürger A, Radsak M, Blum S, Hug F, Hänsch GM: Fibronectin synthesis by activated T lymphocytes: up-regulation of a surfaceassociated isoform with signalling function. Immunology 2000, 99:532-539.

doi:10.1186/1471-2172-11-42

Cite this article as: Sobocinski et al: Ultrastructural localization of extracellular matrix proteins of the lymph node cortex: evidence supporting the reticular network as a pathway for lymphocyte migration. BMC Immunology 2010 11:42.

Submit your next manuscript to BioMed Central and take full advantage of:

- Convenient online submission

- Thorough peer review

- No space constraints or color figure charges

- Immediate publication on acceptance

- Inclusion in PubMed, CAS, Scopus and Google Scholar

- Research which is freely available for redistribution

Submit your manuscript at www.biomedcentral.com/submit 